\title{
Antioxidant and cytotoxic activities of Ageratum conyzoides stems
}

\author{
Fatema Nasrin
}

Department of Pharmacy, Southeast University, Banani, Dhaka-1213, Bangladesh

\begin{abstract}
Modern civilization is facing more than hundreds of disorders associated with free radicals and natural antioxidants from non-edible plants are gaining importance to fight these disorders. The intention of this report is to evaluate a well known medicinal weed Ageratum conyzoides stems for its antioxidant and cytotoxic Effects. Antioxidant potentiality of the crude methanolic extract of the Ageratum conyzoides (AC) stems was investigated on DPPH scavenging activity, reducing ability, total antioxidant capacity as well as total phenolic contents. Cytotoxic study was done by brine shrimp lethality bioassay and vincristin sulphate was used as standard. The total phenols and total antioxidant capacity of AC was found to be $38.125 \pm 2.01 \mathrm{mg} / \mathrm{g}$ equivalent of gallic acid and $333.37 \pm 4.22 \mathrm{mg} / \mathrm{gm}$ equivalent of ascorbic acid, respectively. The percentage (\%) scavenging of DPPH free radical of the extract was found to be concentration dependent with IC 50 value $46.01 \pm 2.23 \mu \mathrm{g} / \mathrm{ml}$ while IC 50 value of standard ascorbic acid was found to be $29.56 \pm 0.11 \mu \mathrm{g} / \mathrm{ml}$. The reducing power of $\mathrm{AC}$ was found to be concentration dependent. The cytotoxicity exhibited by $\mathrm{AC}$ was found promising with $\mathrm{LC}_{50}$ value $1.32 \mu \mathrm{g} / \mathrm{ml}$, comparing with the $\mathrm{LC}_{50}(0.689 \mu \mathrm{g} / \mathrm{ml})$ values of vincristin sulphate. The present investigation suggests that Ageratum conyzoides possesses remarkable antioxidant and cytotoxic property.
\end{abstract}

Key Words: Free radicals, AC, DPPH, total phenolic contents. IC50, brine shrimp lethality bioassay.

\section{INTRODUCTION}

Medicinal plants constitute an effective source of both traditional and modern medicines. Herbal medicine has been revealed to have valid utility and about $80 \%$ rural population depends on its efficacy for their primary health care. Scientist from divergent fields in a similar efforts are investigating flora a new with an eye to their therapeutic worth. A sense of urgency accompanies the search as the pace of species extinction continues. Over the years, the WHO advocated that countries should interact with traditional medicine with a view to identifying and exploiting aspects that provide safe and effective remedies for ailments of both microbial and nonmicrobial origins (WHO 1978). As a part of such study we focused on an annual herb, Ageratum conyzoides L. (Family-Astreracae).

Ageratum conyzoides is erect, $30-80 \mathrm{~cm}$ tall with fine white hairs on the stem and pink flowers (Kaul and

\footnotetext{
Corresponding Author:

Fatema Nasrin

Lecturer

Department of Pharmacy, Southeast University

Banani, Dhaka-1213, Bangladesh

E-mail: nasrin_0209@yahoo.com

Contact No.: +8801913714999
}

Neelangini, 1989). It is a weed, commonly called Billygoat-weed, Goatweed etc., generally found in cultivated fields and other ecosystems such as pastures, grasslands, wastelands and even forest areas (Batish et al., 2006). The plant is known to have originated from tropical America and now spread to various tropical and subtropical parts of the world (Juliana et al., 2010). This plant is widely utilized in traditional medicine wherever it grows (Bioka et al., 1993). It has been long known in herbal or folk medicine as a remedy for diverse ailments in Africa (Almagboul et al., 2001) and worldwide. Various pharmacological investigations have verified its antibiotic efficacy (Durodola, 1977), analgesic effect in rats (Menut et al., 1993), antioxidative effect (Jagetia et al., 2003), hepatoprotective effects (Ita et al., 2009) and as a blood booster (Ita et al., 2007). The phytochemical screening showed that $A$. conyzoides contains alkaloids, resins, saponins, tannins, glycosides and flavonoids (Kamboj and Saluja, 2008). Many different compounds have been isolated and identified in $A$. conyzoides; such as kaempferol and glycoside (rhamnoside); quercetin, scutellarein, eupalestin, chromene, stigmas-7-en-3ol, sitosterol, stigmasterol, fumaric acid, caffeic acid, saponin, pyrrolizidinic alkaloids, ageratochromene 
derivatives and alkane (Nyuna et al., 2010). Furthermore, Ageconyfavones A, B, and C; hexametoxyflavone; three coumarinic compounds, including 1-2 benzopirone; 1,2- desifropirrolizidinic and licopsamine have been identified in $A$. conyzoides (Kamboj and Saluja, 2008; Ladeira et al., 1987). The whole plant is traditionally used in management of wounds, burns and bacterial diseases (Ming, 1999). No studies on cytotoxic and antioxidant effect of $A$. conyzoides have so far been undertaken. Taking this in view and as a part of our ongoing research on Bangladeshi medicinal plants, the present study aimed to evaluate the antioxidant and cytotoxic activity of the methanolic extract of $A$. conyzoides stems.

\section{MATERIALS AND METHODS}

\section{Plant material}

The plant A. conyzoides were collected in the month of March 2012 from Jamalpur, Bangladesh. A voucher specimen for this collection has been maintained in the Bangladesh National Herbarium (Voucher Specimen No - DACB 37866), Dhaka, Bangladesh.

\section{Preparation of the extract}

The stems of the plant were first washed with water to remove adhering dirt and then dried at $45^{\circ} \mathrm{C}$ for $36 \mathrm{hrs}$ in an electric oven, then powdered with a mechanical grinder, passing through sieve \# 40, and stored in a tight container. The dried powdered material $(1 \mathrm{~kg})$ was taken in a clean, flat bottomed glass container and soaked in methanol for seven days. The whole mixture then underwent a coarse filtration by a piece of clean, white cotton material. The total filtrate was concentrated to dryness, in vacuo at $40^{\circ} \mathrm{C}$ to render the methanol extract $(390 \mathrm{~g})$ of brownish red color.

\section{Drugs and chemicals}

The active drugs Diazepam were the generous gift samples from Square Pharmaceuticals Ltd., Bangladesh. Ammonium molybdate (Merck, Germany), Sodium phosphate (BDH, England), Potassium ferri-cyanide $\left(\mathrm{K}_{3}\left[\mathrm{Fe}(\mathrm{CN})_{6}\right]\right)$ Trichloroacetic acid $\left(\mathrm{CCl}_{3} \mathrm{COOH}\right)$, Folin-Ciocalteu reagent, DPPH free radical, ascorbic acid, gallic acid was obtained from Merck, Germany. All chemicals used were of analytical reagent grade.

\section{In vitro antioxidant activity}

\section{The amount of phenolic compounds}

The total phenolic content of AC was determined using Folin-Ciocalteu reagent ( $\mathrm{Yu}$ et al., 2002). The content of total phenolic in the extract of AC was calculated from regression equation of the calibration curve $\left(\mathrm{y}=0.0138 \mathrm{x}+0.1275, \mathrm{R}^{2}=0.988\right)$ and is expressed as Gallic acid equivalents (GAE).

\section{Determination of total antioxidant capacity}

The antioxidant activity of the extract was evaluated by the phosphomolybdenum method (Prieto et al., 1999). The assay is based on the reduction of Mo (VI)-Mo (V) by the extract and subsequent formation of a green phosphate/Mo (V) complex at acid $\mathrm{pH}$. The total antioxidant of AC was calculated from regression equation of the calibration curve $(\mathrm{y}=$ $\left.0.0043 x+0.1503, R^{2}=0.8874\right)$ and is expressed as ascorbic acid equivalents (AAE)

Free radical scavenging activity measured by 1, 1diphenyl-2-picryl-hydrazyl (DPPH)

The free radical scavenging activity of the extract, based on the scavenging activity of the stable 1, 1diphenyl-2- picrylhydrazyl (DPPH) free radical was determined by the method described by Braca (Braca et al., 2001). The $0.1 \mathrm{mmol} / \mathrm{L}$ solution of DPPH in methanol was prepared and $1 \mathrm{ml}$ of this solution was added to $3 \mathrm{~mL}$ of extract's solution at different concentrations $(5,10,25$ and $50 \mu \mathrm{g} / \mathrm{mL})$. After $30 \mathrm{~min}$, absorbance was measured at $517 \mathrm{~nm}$. Vitamin C (ascorbic acid) was used as a reference drug. The percentage inhibition activity was calculated from $\left[\left(\mathrm{A}_{0}-\mathrm{A}_{1}\right) / \mathrm{A}_{0}\right] \times 100$, where $\mathrm{A}_{0}$ is the absorbance of the control, and $\mathrm{A}_{1}$ is the absorbance of the extract/ standard. Median inhibitory concentration $\left(\mathrm{IC}_{50}\right)$ value was calculated from the equation of line obtained by plotting a graph of concentration $(\mu \mathrm{g} / \mathrm{ml})$ versus $\%$ inhibition.

\section{Reducing power activity}

The reducing power of AC was determined according to the method described by Oyaizu (Oyaizu, 1986). For the measurement of the reductive ability, transformation of Ferric ion to Ferrous ion was investigated in the presence of extracts. Increased absorbance of the reaction mixture indicated increased reducing power. Ascorbic acid was used as the standard. Phosphate buffer ( $\mathrm{pH}$ 6.6) was used as blank solution. The absorbance of the final 


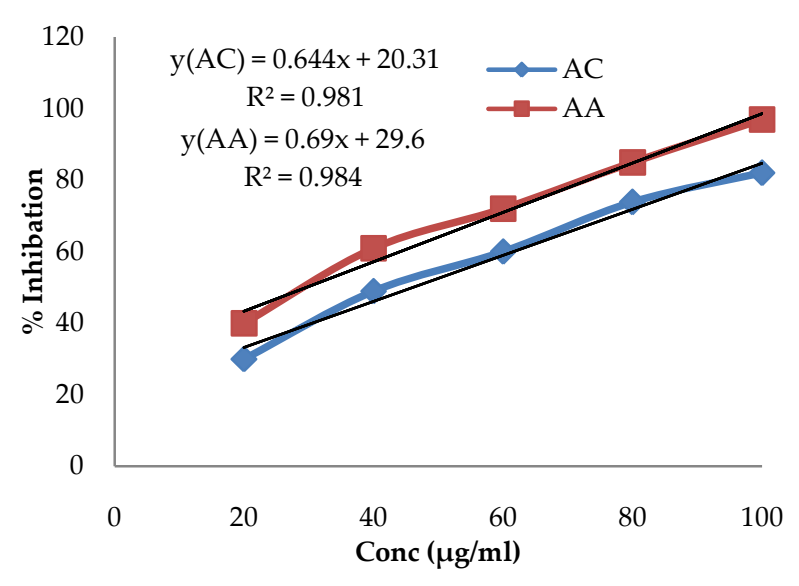

Figure 1: Free radical scavenging activity of different concentrations of methanolic extract of $A$. conyzoides and ascorbic acid by DPPH radicals.

reaction mixture of two parallel experiments was taken and is expressed as mean \pm standard deviation. Increased absorbance of the reaction mixture indicated increased reducing power.

\section{Cytotoxic activity}

Brine shrimp lethality bioassay (Rahman and Rashid, 2008) technique was applied for the determination of general toxic property of AC. Here, in vivo lethality test has been carried out using brine shrimp nauplii eggs (Artemia salina). Vincristin sulphate was used as a positive control in the bioassay. Eggs were placed in one side of a small tank divided by a net containing $3.8 \% \mathrm{NaCl}$ solution for hatching. In the other side of the tank was placed a light source to attract the nauplii. After 2 days of hatching period the nauplii were ready for the experiment. Four milligrams of the complexes was accurately measured and dissolved in DMSO to get a concentration of varying concentrations 100, 50, $25,12.50,6.25,3.125,1.563,0.781,0.39,0.19 \mu \mathrm{g} / \mathrm{ml}$. Ten brine shrimp nauplii were then placed in each vial. For the control test of each vial, one vial containing the same volume of DMSO plus water up to $5 \mathrm{ml}$ was used. After 24 hour of incubation, the vials were observed using a magnifying glass and the number of survivors in each vial were counted and noted. From these data, the percentage of mortality of the nauplii was calculated for each concentration and the 50\% leathal concentration (LC50) values were determined.

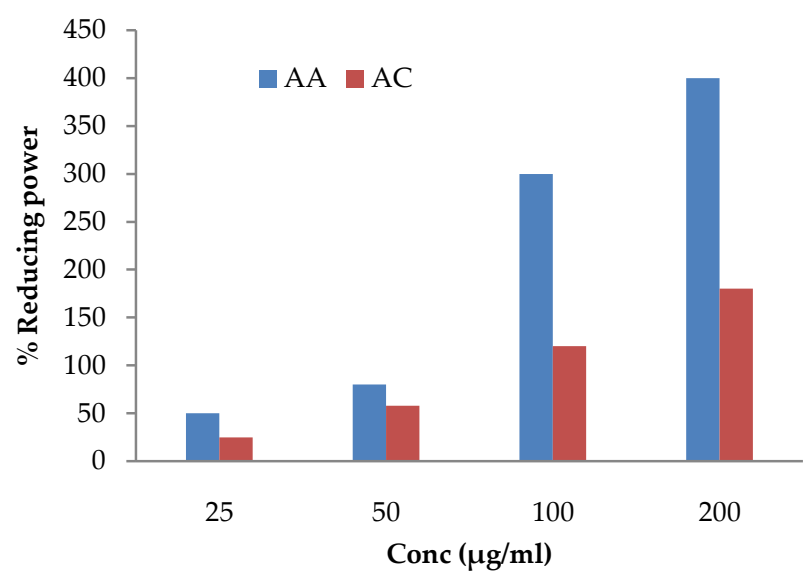

Figure 2: Reducing power of methanolic extract of $A$. conyzoides and ascorbic acid by spectophotometric detection of $\mathrm{Fe}^{3+}$ to $\mathrm{Fe}^{2+}$ transformation.

\section{RESULTS}

In vitro antioxidant activity

Total phenolic contents

The total phenols content was found to be $38.38 \pm$ $2.01 \mathrm{mg} / \mathrm{g}$ plant extract (in GAE) in crude extract of AC.

\section{Total antioxidant capacity}

Total antioxidant capacity of AC is expressed as the number of equivalents of ascorbic acid and found to be $333.37 \pm 4.22 \mathrm{mg} / \mathrm{gm}$ equivalent of ascorbic acid (AAE).

\section{DPPH radical scavenging activity}

The percentage (\%) scavenging of DPPH free radical was found to be concentration dependent i.e. concentration of the extract between $25-200 \mu \mathrm{g} / \mathrm{ml}$ greatly increasing the inhibitory activity (Figure 1). The IC 50 value was found to be $46.01 \pm 2.23 \mu \mathrm{g} / \mathrm{ml}$ and $29.56 \pm 0.11 \mu \mathrm{g} / \mathrm{ml}$ for AC and standard ascorbic acid, respectively.

\section{Reducing power ability}

For the measurement of the reductive ability, we investigated the $\mathrm{Fe}^{3+}$ to $\mathrm{Fe}^{2+}$ transformation in the presence of $\mathrm{AC}$ and compared with standard ascorbic acid (Figure 2). The reducing power of AC was found to be concentration dependent.

\section{Cytotoxic activity}

In cytotoxic test activity, \% mortality increased gradually with the increase in concentration of the test samples. $\mathrm{LC}_{50}$ values obtained from the best-fit line slope (Figure 3) were $1.32 \mu \mathrm{g} / \mathrm{ml}$ and $0.689 \mu \mathrm{g} / \mathrm{ml}$ for $A C$ and vincristine sulphate, respectively. 


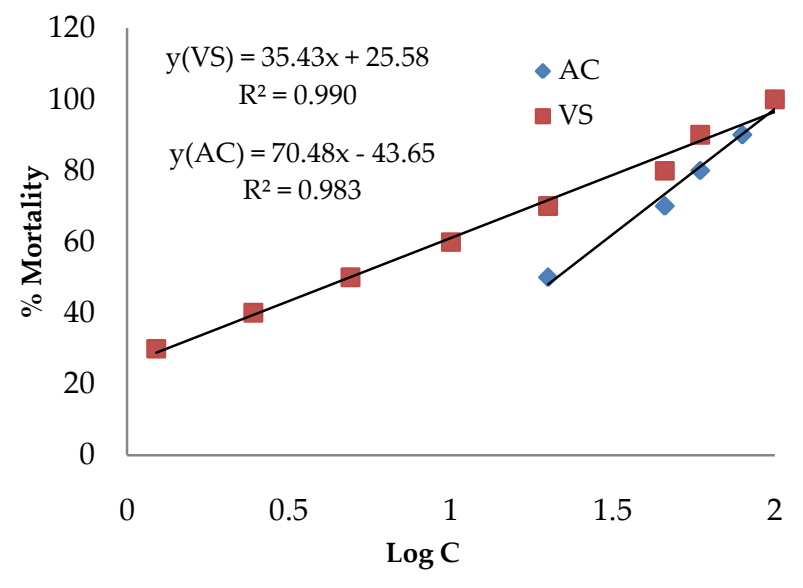

Figure 3: Determination of $\mathrm{LC}_{50}$ values for vincristine sulphate and methanolic extracts of $A$. conyzoides from linear correlation between logarithms of concentration versus percentage of mortality.

\section{DISCUSSION}

Recently safety considerations, public's perception and risk reduction of chronic diseases by consumption of fruits and vegetables, have geared interest in the search for natural antioxidants (Dastmalchi et al., 2007). In aerobic environment, all animals and plants require oxygen and hence free radicals (reactive oxygen species) are ubiquitously present. But excess generation of free radicals cause depletion of immune system antioxidants, alter in gene expression and induce abnormal proteins and contribute to more than one hundred disorders in humans including atherosclerosis, arthritis, ischemia and reperfusion injury of many tissues, central nervous system injury, gastritis, cancer and AIDS. Antioxidant can protect the body by preventing the formation of free radicals, by bringing interruption in Free radicals attack, by scavenging the reactive metabolites or by converting them to less reactive molecules (Hegde and Joshi, 2009). We evaluated the antioxidant effect of $\mathrm{AC}$ considering these mentioned parameters.

Polyphenolic phytochemicals, flavonoids and phenol have been reported from AC which is suggested to have multiple biological effects, including antioxidant activity (Kahkonen et al., 1999). Phenolic compounds are implicit to induce the cellular antioxidant system by approximately $50 \%$ cellular glutathione concentration increasement. Flavonoids are significant in the modulation of $\gamma$-glutamylcysteine synthase in both cellular antioxidant defenses and detoxification of xenobiotics (Muchuweti et al., 2007). We have got phenol content $38.38 \pm 2.01 \mathrm{mg} / \mathrm{g}$ which may be the cause for the antioxidant activity of AC in different models. The proton-donating ability of this extract was evaluated through $\mathrm{DPPH}$ assay and reducing ability. IC 50 value of AC close to standard ascorbic acid in DPPH assay was found very promising indicating its capacity of having scavenged the free radicals efficiently.

Reducing power of any extract will be given by the amount of reductones present in them. The ability of the hydroxyl groups present in the flavonoids / phenolics to reduce the free radicals by donating their electrons will determine their activity. Dose dependent reducing ability of any extract exerted antioxidant action by breaking the free radical chain by donating hydrogen atom (Duh et al., 1999). So, these antioxidant potentiality of AC are an important approach for the management of oxidative stress ailment.

The brine shrimp lethality bioassay is very useful to assess the bioactivity of the plant extracts which in most cases correlates reasonably well with cytotoxic and anti-tumor properties (McLauglin et al., 1993). $\mathrm{LC}_{50}$ values of $\mathrm{AC}$ revealed its considerable cytotoxic potency. Huge amount of phenolics and flavonoids present in AC might be responsible for its promising cytotoxic activity (Okwori et al., 2007; Moreira et al., 2007) and the possible mechanism of cytotoxicity against brine shrimp nauplii due to poisonous effect on cell mitosis.

\section{CONCLUSION}

This work has demonstrated that the methanolic extracts of Ageratum conyzoides stems possesses promising antioxidant and cytotoxic potentiality, thereby lends support to the traditional use of the plant in infectous and inflammatory disorders. However, further studies are needed to be conducted to understand the exact mechanisms of such actions and to isolate the active principles responsible for the observed activity. 


\section{REFERENCES}

Almagboul, A.Z., Farroq, A.A., and Tyagi, B.R.(1985) Antimicrobial activity of certain Sudanese plants used in folkloric medicine: Screening for antibacterial activity, part II. Fitoterapia 56:103-109.

Batish, D.R., Singh, H.P., Kaur, S. and Kohli, R.K.( 2006) Phytotoxicity of Ageratum conyzoides residues towards growth and nodulation of Cicer arietinum. Agriculture, Ecosystems and Environment, 113: 399-401. [DOI]

Bioka, D., Banyikwa, F. and Choudhuri, A. (1993) Analgesic effect of a crude extract of Ageratum conyzoides in the rat. Acta Hort, 332: 171-176.

Braca, A., Tommasi, N.D., Bari, L.D., Pizza, C., Politi, M. and Morelli, I. (2001) Antioxidant principles from Bauhinia terapotensis. Journal of Natural Product, 64:892-895. [DOI]

Bruce, R.D. (1985) An up and down procedure for acute toxicity testing. Fundamental Applied Toxicology, 5:151-157. [DOI]

Dastmalchi, K., Dorman, H.J.D., Kos-ar, M. and Hiltunen, R. (2007) Chemical composition and in vitro antioxidant evaluation of a water soluble Moldavian balm (Dracocephalum moldavica L) extract. Food Science Technology, 40: 239-248. [DOI]

Duh, P.D., Tu, Y.Y. and Yen, G.C. (1999) Antioxidant activity of water extract of Harng Jyur (Chrysanthemum morifolium Ramat). Lebensmittel-Wissenschaft Technology, 32: 269-277. [DOI]

Durodola, J. J. (1997) Antibacterial property of crude extracts from herbs wound healing remedy-Ageratum conyzoides. Planta Medicine, 32: 388-390.

Hegde, K. and Joshi, A.B. (2009) Hepatoprotective effect of Carissa carandas Linn root extract against $\mathrm{CCl}_{4}$ and paracetamol induced hepatic oxidative stress. Indian Journal of Experimtal Biology, 47: 660-667. [DOI]

Ita, S.O., Etim, O.E., Ben, E.E. and Ekpo, O.F. (2007) Haematopoietic properties of ethanolic leaf extract of Ageratum conyzoides (Goat weed) in albino rats. Nigerian Journal of Physiology and Science, 22: 83-87.

Ita, S.O., Akpanyung, E.O., Umoh, B.I., Ben E.E. and Ukafia, S.O. (2009) Acetaminophen Induced Hepatic Toxicity: Protective Role of Ageratum conyzoides. Pakistan Journal of Nutrition, 8: 928-932.

Jagetia, G.C., Shirwaikar, A., Rao, S.K. and Bhilegaonkar, P.M. (2003) Evaluation of the radioprotective effect of Ageratum conyzoides Linn extract in mice exposed to different doses of gamma radiation. Journal of Pharmacy and Pharmacology, 55: 1151-1158. [DOI]

Juliana, H.C. N., Edlayne, G., Silvia, R., G., Roseane, F., Márcia O.M. M. and Joana D. F. (2010) Ageratum conyzoides essential oil as aflatoxin suppressor of Aspergillus flavus. International Journal of Food Microbiology, 137: 55-60.

Kahkonen, M.P., Hopia, A.I., Vuorela, H.J., Rauha, J.P., Pihlaja, K., Kulaja, T.S. et al. (1999) Antioxidant activity of plant extracts containing phenolic compounds. Journal of Agriculture and Food Chemistry, 47: 3954-3962.

Kamboj, A., and Saluja, A.K. (2008) Ageratum conyzoides L.: A review on Its phytochemical and pharmacological profile. International Journal of Green Pharmacy, 2: 59-68. http://dx.doi.org/10.4103/0973-8258.41171
Kaul, M.L.H. and Neelangini, S. (1989) Male sterility in diploid Ageratum conyzoides L. Cytologia 54: 445-448. [DOI]

Kolawole, O.T., Makinde, J.M. and Olajid, O.A. (2007) Central nervous depressant activity of Russelia equisetiformis. Nigeria Journal of Physiology Science, 22: 59-63.

Ladeira, A.M., Zaidan, L.B.P. and Figueiredo-Ribeiro, R.C.L. (1987) Ageratum conyzoides L.(Compositae):Germinação, floração e ocorrência de derivados fenólicos em diferentes estádios de desenvolvimento. Hoehnea 15: 53-62.

McLauglin, J. L., Chang, C. J., and Smith, D. L. (1993) Simple bench-top bioassays (brine shrimp and potato discs) for the discovery of plant antitumour compounds. In: Human Medicinal Agents from Plants. Kinghorn, A. D. and Balandrin, M. F. (Eds.), ACS Symposium 534, American Chemical Society, Washington, D. C.: 112-137.

Menut, C., Lamaty, G. and Amvam, P.H. (1993) Aromatic plants of tropical central Africa part X: Chemical composition of essential oil of Ageratum houstonianum. Flavour and Fragrance Journal, 8: 1-1. [DOI]

Moreira, M.D., Picanço M.C., Barbosa, L.C., Guedes, R.N., Barros, E.C. and Campos, M.R. (2007) Compounds from Ageratum conyzoides: isolation, structural elucidation and insecticidal activity. Pest Management Science, 63: 615- 621. [DOI]

Ming, L.C. (1999) Ageratum conyzoides: A tropical source of medicinal and agricultural products.. In: J. Janick (ed.) Perspectives on new crops and uses. ASHS (American Society for Horticultural Science) Press, Alexandria, VA, USA. :469-473.

Muchuweti, M., Kativu, E., Mupure, C.H., Chidewe, C., Ndhlala, A.R. and Benhura, M. (2007) Phenolic composition and antioxidant properties of some spices. American Journal of Food Technology, 2: 414-420.

Nyuna, N., Manguelle-Dicoum, A., Njifutié, N. et al., (2010) Antihyperglycaemic effect of Ageratum conyzoides L. fractions in normoglycemic and diabetic male wistar rats. International Journal of Biomedical and Pharmaceutical Sciences, 4(1): 38-42.

Okwori, A.E.J., Dina, C.O., Junaid, S., Okeke , I.O., Adetunji, J.A. and Olabode, A.O.

(2007). Antibacterial Activities of Ageratum conyzoides extracts on selected bacterial pathogens. International Journal of Microbiology, 4: 1937- 1949.

Oyaizu, M. (1986) Studies on product of browning reaction prepared from glucose amine. Japanese Journal of Nutrition and Dietetics, 44:307-315. [DOI]

Prieto, P., Pineda, M. and Aguilar, M. (1999) Spectrophotometric quantitation of antioxidant capacity through the formation of a phosphomolybdenum complex: Specific application to the determination of vitamin E. Analytical Biochemistry, 269:337341. [DOI]

Rahman, M.S., and Rashid, M.A. (2008) Antimicrobial activity and cytotoxicity of Eclipta prostrata. Oriental Pharmacy and Experimental Medicine, 8: 47-52. [DOI]

Roginsky, V., Lissi, E.A. (2005) Review of methods to determine chain breaking antioxidant activity in food. Food Chemistry, 92: 235. [DOI]

Yu L, Haley S, Perret J, Harris M, Wilson J, Qian M. (2002) Free radical scavenging properties of wheat extracts. Journal of Agriculture and Food Chemistry, 50:1619-1624. [DOI] 